\title{
OPEN Toxic and heavy metals contamination assessment in soil and water to evaluate human health risk
}

\author{
Waqar Ahmad ${ }^{1}$, Rima D. Alharthy ${ }^{2 \bowtie}$, Muhammad Zubair ${ }^{1 \bowtie}$, Mahmood Ahmed $^{3 凶}$, \\ Abdul Hameed ${ }^{4}$ \& Sajjad Rafique ${ }^{1}$
}

Due to urbanization and industrialization, there has been an increase in solid waste generation and has become a global concern and leakage of leachate from landfills contaminate the soil and groundwater and hence can have a severe impact on human health. The present study aimed to determine the composition of toxic metals $(\mathrm{Cr}, \mathrm{Mn}, \mathrm{Cu}, \mathrm{As})$ and heavy metals $(\mathrm{Cd}, \mathrm{Ba}, \mathrm{Hg}, \mathrm{Pb})$ in soil and water by an inductively coupled plasma optical emission spectrometer (ICP-OES). To ensure accuracy during the analysis of $\mathrm{Cr}, \mathrm{Mn}, \mathrm{Cu}, \mathrm{As}, \mathrm{Cd}, \mathrm{Ba}, \mathrm{Hg}$, and $\mathrm{Pb}$ in real samples, certified reference material (CRM, SRM 2709a) of San Joaquin soil and water (SRM 1640a) were analyzed and results were presented in terms of \% recovery studies. The mean concentration of all the metals in soil and water did not exceed the limit set by the European Community (EU), WHO, and US EPA except Cu where the permissible limit defined by the EU is $50-140 \mathrm{mg} / \mathrm{kg}$ in soil. The soil is uncontaminated to moderately contaminated with respect to all metals except the $\mathrm{Cu}$ and $\mathrm{Pb}$. Among the average daily dose (ADD) of soil, $A D D_{\text {ing }}$ and $A D D_{\text {inh }}$ for children had the maximum dose for all metals than adults while $A D D_{\text {derm }}$ was higher in adults. Hazard quotient $(\mathrm{HQ})$ trend in both adults and children was found in order $\mathrm{HQ}_{\text {ing }}>\mathrm{HQ}_{\text {derm }}>\mathrm{HQ}_{\text {inh }}$ of soil for all metals except Ba which followed $\mathrm{HQ}_{\text {ing }}>\mathrm{HQ}_{\text {inh }}>\mathrm{HQ}_{\text {derm }}$. Hazard index ( $\mathrm{HI})$ values of soil for $\mathrm{Cr}$ and $\mathrm{Pb}$ in children were 7 and 7.5 times higher than adults respectively. Lifetime cancer risk (LCR) value for $\mathrm{Cr}$ by different exposure pathways of soil was $5.361 \times 10^{-4}$ for children which are at the lower borderline of risk for cancer.

Despite much awareness about solid waste, it is increasing day by day due to anthropogenic activities throughout the world. Due to urbanization and industrialization, there has been an increase in solid waste generation and has become a global concern ${ }^{1}$. Effective management of solid waste is being geared up in both developed and developing countries due to its adverse effect and impact on human health and the environment respectively ${ }^{2}$. Among the waste management methods, landfilling is a primary method of disposing of and has gained acceptance because it is simple and has considerable advantages like economic efficiency and low technological barriers ${ }^{3}$. If the landfill site does not have an appropriate system like leachate liner and its collection then it possesses a potential risk to soil and groundwater aquifer near the area surrounding the landfill site. The leakage of leachate from landfills contaminates the groundwater, soil, surface water, and natural ecosystems especially when the leachate is released uncontrolled, and hence can have a severe impact on environmental and human health ${ }^{4,5}$. Moisture in soil under favorable environmental factors generates the leachate from landfills which can enter into the soil and aquatic environments ${ }^{6,7}$.

The presence of several pollutants including suspended particles (organic and inorganic), toxic (TMs), and heavy metals (HMs) in landfill leachate is a matter of concern and it can pose a serious threat to public health as well as ecotoxicological impacts on terrestrial and aquatic ecosystems ${ }^{1,8,9}$. Soil is an important part of the terrestrial ecosystem and it is the ultimate sink for HMs and becomes a medium to spread them into water bodies, organisms, and atmosphere. HMs are persistent and accumulative in soil and increase the toxicity of soils after combining with inorganic and organic matters. So HMs can accumulate in the food chain, then enter the human

${ }^{1}$ Department of Chemistry, University of Gujrat, Gujrat, Pakistan. ${ }^{2}$ Department of Chemistry, Science and Arts College, Rabigh Campus, King Abdulaziz University, Jeddah 21577, Saudi Arabia. ${ }^{3}$ Renacon Pharma Limited, Lahore 54600, Pakistan. ${ }^{4}$ Department of Chemistry, University of Sahiwal, Sahiwal, Pakistan. ${ }^{\square}$ email: iaaalharte@ kau.edu.sa; muhammad.zubair@uog.edu.pk; mahmoodresearchscholar@gmail.com 
body through food consumption. HMs can also accumulate in the human body via dermal contact absorption and direct ingestion and inhalation ${ }^{10,11}$. Drinking of water and inhalation of soil particles have been identified as the major pathway for human exposure to toxic metals ${ }^{12,13}$.

The impact of Cr upon human health is dependent upon the oxidation state because Cr (III) is an important ingredient of human diet and plays a significant role in human metabolism whereas $\mathrm{Cr}$ (VI) is highly carcinogenic as well causing cardiovascular and liver diseases ${ }^{14}$. Mn plays an important role in the metabolism of carbohydrates, cholesterol, and amino acids metabolism. Higher concentrations of Mn can cause several effects like male infertility, neurological disorders, birth disability, and bone defects ${ }^{15}$. Cu has a significant role in the physiological function of the human body but excessive ingestion can have unfavorable effects on human health. The $\mathrm{Cu}$ in excess amount has noxious effects on the intestine, liver and damage the stomach ${ }^{16-18}$. As if ingested in higher concentrations can lead to skin cancer, dermal lesions, angiosarcoma, peripheral neuropathy, and vascular disease $\mathrm{e}^{19,20}$. Cd if present in excess can damage the lungs, liver, induces osteotoxicity and nephrotoxicity, pulmonary adenocarcinomas, prostatic proliferative lesions, pulmonary adenocarcinomas and disturbs the immune system of the body ${ }^{21,22}$. Ingestion of $\mathrm{Ba}$ can cause changes in heart rhythm or paralysis in humans and may cause mortality if did not seek medical advice. Exposure to Ba for a short period may experience difficulties in breathing, irregulation in blood pressure, diarrhea, vomiting, diarrhea, and muscle weakness ${ }^{23}$. Cysteine residue of protein and $\mathrm{Hg}$ (II) form a covalent bond that results in depletion of cellular antioxidants, so $\mathrm{Hg}$ produces reactive oxygen reactive species (ROS) as a result of oxidative damage and oxidative damage describe the molecular mechanism of toxicity. The carcinogenic process initiates as a result of DNA damage in cells which is caused by ROS because ROS play a major role in the metal induced cellular responses ${ }^{24,25}$. Excessive concentration of $\mathrm{Pb}$ in the blood can cause hypertension, damage the skeletal, immune system, endocrine, reduces intelligence potential in kids and among adults it also affects the functioning of kidney and heart ${ }^{26-28}$.

So the presence of TMs (Cr, Mn, Cu, and $\mathrm{As})$ and $\mathrm{HMs}(\mathrm{Cd}, \mathrm{Ba}, \mathrm{Hg}, \mathrm{Pb})$ in soil and water can cause serious damage to human health. Contamination of soil and groundwater with TMs and HMs surrounding the industrial landfills becomes one of the most challenging environmental and health issues because of their persistence, toxicity, bioaccumulation, and non-biodegradability ${ }^{29-31}$.

Within this context, our study is to investigate the TMs and HMs composition in the soil and groundwater by inductively coupled plasma-optical emission spectroscopy (ICP-OES). Therefore, the aim of this study to assess the contamination level of the aforementioned metals in the soil and groundwater near the industrial landfill sites in Sialkot (an industrial city in the province of Punjab-Pakistan). Geo-accumulation index $\left(\mathrm{I}_{\text {geo }}\right)$, contamination factor (CF) and potential ecological risk index (PERI) were determined to assess pollution, evaluate the pattern of contamination and determine the potential risk due to exposure to ecological sensitivity, concentration and toxicity of TMs and HMs in soil. Information about these metals is equally important for assessing their potential risk to human health, so the average daily dose (ADD), the non-carcinogenic target hazard quotient (THQ), and carcinogenic risk (CR) coefficients were demonstrated to evaluate the human health risk.

To the best of our knowledge, no previous study was conducted for the estimation of TMs and HMs in soil and water near the industrial landfill site. So different regions surrounds the landfill site were chosen to study the TMs and HMs composition in soil and water to estimate the potential health risk of these metals on human health and ecosystems. This study also aimed to provide helpful information by computing various contamination factors for scientific management of industrial activities for pollution control in relation to ecosystems and human health risk.

\section{Materials and methods}

Study area. The study was conducted in the industrial city of Sialkot ( $32^{\circ} 29^{\prime} 33.65^{\prime \prime} \mathrm{N}$ and $\left.74^{\circ} 31^{\prime} 52.82^{\prime \prime} \mathrm{E}\right)$ in the province of Punjab-Pakistan (Fig. 1). The city is renowned for manufacturing of leather items including sports and surgical instrument. The study area is based on $19 \mathrm{~km}^{2}$. The total population of the city was 477,396 in 2019. The mean annual temperature of the study area was $29.6^{\circ} \mathrm{C}$, June is the hottest month with a temperature of $39.0^{\circ} \mathrm{C}$ and the coldest month is January with a temperature of $6.0^{\circ} \mathrm{C}$. The average temperature range in April $19-34^{\circ} \mathrm{C}$ and in October $18-31^{\circ} \mathrm{C}$, with average humidity about $50-69 \%$ respectively. Roughly $3 / 4$ of the waste produced from leather industries, while the remaining is contributed by surgical equipment manufacturing industries. Solid waste from industries dump in empty plots/yards and these landfills were not lined but had compacted clay at the base to minimize seepage of leachate into the subsurface environment.

Reagents and solutions. Hydrofluoric acid (HF, $48 \% \mathrm{~m} / \mathrm{m})$, Nitric acid, $\left(\mathrm{HNO}_{3}, 65 \% \mathrm{~m} / \mathrm{m}\right)$, for the preparation of solution for digestion of soil, were purchased from Hajvery Scientific Store, Lahore-Pakistan originate to Merck, Germany. Certified reference material of each element (1000 mg L ${ }^{-1}$, Merck, Germany) was employed for instrument calibration after diluting it with $\mathrm{HNO}_{3}(2 \% \mathrm{v} / \mathrm{v})$. Ultrapure water $(18 \mathrm{M} \Omega . \mathrm{cm}$ resistivity) for the dilution of all solutions was prepared by the GenPure water system (Thermo Scientific, USA). All glassware and materials used in the procedure were soaked in nitric acid $(20 \% \mathrm{v} / \mathrm{v})$ and then exhaustively washed with ultrapure water. Certified reference materials (SRM 2709a) of San Joaquin soil and water (SRM 1640a) were used as a reference.

Collection, preparation, analysis of soil and water samples. For soil analysis, a systematic sampling approach was adopted for the collection of soil samples by distributing the study area into four regions such as east (region I), west (region II), north (region III), south (region IV). From each region, five samples were collected at a distance of 10-50 m (after a consecutive distance of $10 \mathrm{~m}$ ) from the landfill site and in total twenty samples were collected ( 5 samples $\times 4$ regions). About $500 \mathrm{~g}$ sample was collected from each sample point a depth of $0.5-20,20-40,40-60 \mathrm{~cm}$ while the top $0.5 \mathrm{~cm}$ of surface soil was removed before sampling. Each sample is 


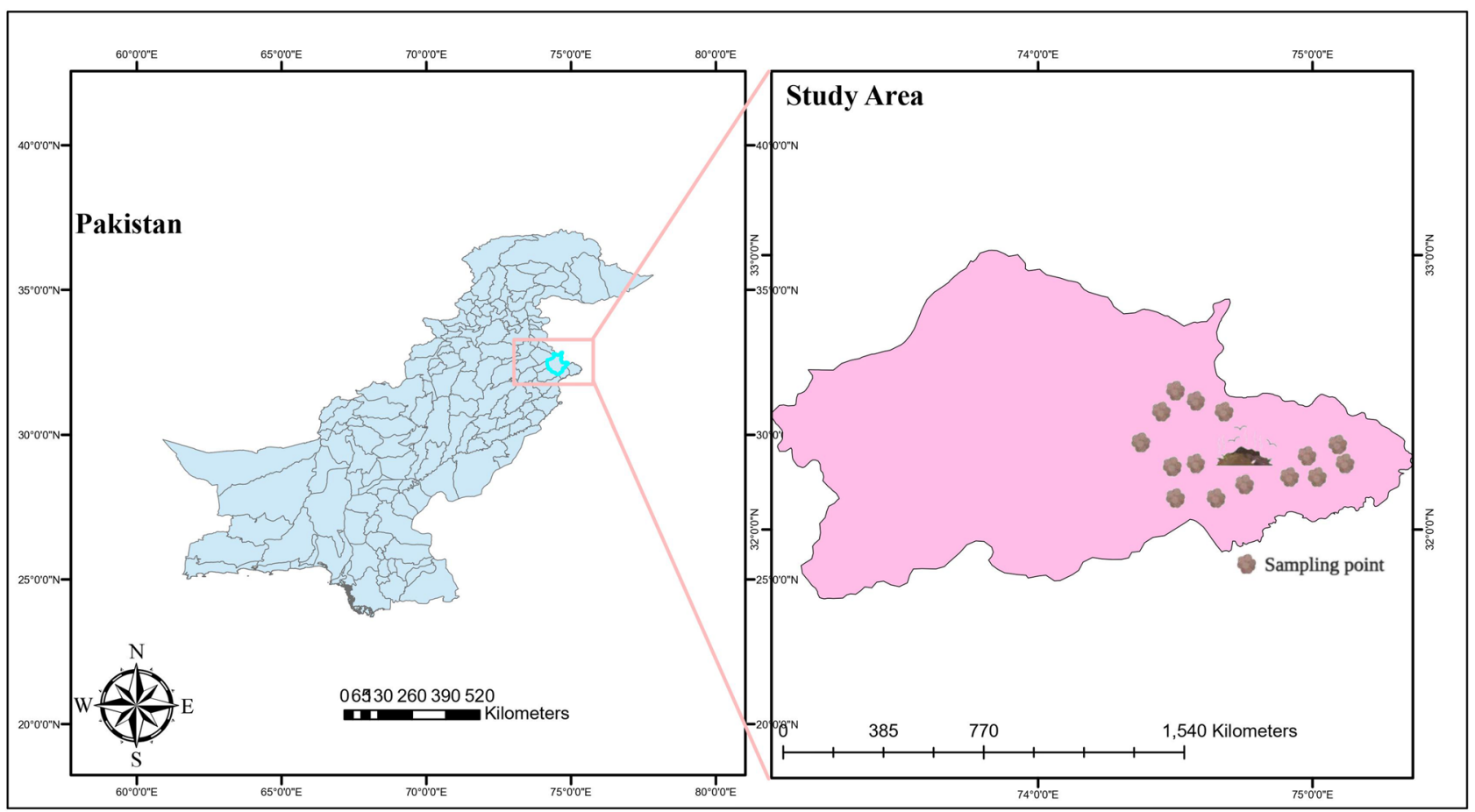

Figure 1. Study area.

\begin{tabular}{|l|l|}
\hline ICP-OES & $\begin{array}{l}\text { Thermo Fisher Scientific, iCAP 7400 with the radial viewed plasma equipped with echelle type 52.91 } \\
\text { grooves/mm ruled grating }\end{array}$ \\
\hline RF power & $1250 \mathrm{~W}$ \\
\hline Radial viewing height & $8 \mathrm{~mm}$ \\
\hline Plasma coolant gas flow rate & $15.0 \mathrm{~L} \mathrm{~min}^{-1}$ \\
\hline Auxiliary gas flow rate & $1.0 \mathrm{~L} \mathrm{\text {min}^{-1 }}$ \\
\hline Nebulizer gas flow & $0.65 \mathrm{~L} \mathrm{~min}^{-1}$ \\
\hline Nebulizer type & V-groove, pressure $240 \mathrm{kPa}$ \\
\hline Sample uptake rate & $1.5 \mathrm{~mL} \mathrm{~min}^{-1}$ \\
\hline Pump rate & $35 \mathrm{rpm}$ during flushing, $20 \mathrm{rpm}$ during the analysis \\
\hline Spectral lines $(\mathrm{nm})$ & $\mathrm{Cr}: 267.716, \mathrm{Mn}: 257.610 \mathrm{Cu}: 327.393 \mathrm{As}: 188.980, \mathrm{Cd}: 214.439, \mathrm{Ba}: 455.403 \mathrm{Hg}: 194.164 \mathrm{~Pb}: 220.353$ \\
\hline
\end{tabular}

Table 1. ICP-OES operational parameters.

comprised of three subsamples which are pooled and homogenized to form a representative sample. The representative samples were coded as SLNS1-SLNS5, SLSS1-SLSS5, SLES1-SLES5, and SLWS1-SLWS5 mean five samples from each region and transported to the laboratory after packed in a polyethylene bag. The samples were air-dried at $35^{\circ} \mathrm{C}$ for $72 \mathrm{~h}$ using an air circulation oven (Vision Scientific, Korea), crushed, passed through a sieve of mesh size No. 10, and stored in polyethylene bottles before acid digestion followed by metal analysis. $1 \mathrm{~g}$ of soil representative sample was weighed and transferred to porcelain crucible already contained $10 \mathrm{~mL}$ mixture of $\mathrm{HNO}_{3}$ and $\mathrm{HF}(1: 1)$, the residue was formed after drying in a water bath after which the residue was dissolved in $20 \mathrm{~mL} \mathrm{HNO}_{3}(2 \mathrm{M})$. Whatman No. 41 filter paper was used to remove the particles in the resulting solution, then the solution was transferred to a $100 \mathrm{~mL}$ measuring flask and made the volume up to mark with ultrapure water ${ }^{32}$.

For water analysis, twenty samples were also collected from boreholes in $1 \mathrm{~km}^{2}$ surrounding of landfill site were coded as SLNW1-SLNW5, SLSW1-SLSW5, SLEW1-SLEW5, and SLWW1-SLWW5, to eliminate immobile water samples were fetched after pumping for $15 \mathrm{~min}$ while the samples were collected into clean polyethylene bottles having a capacity of $1.0 \mathrm{~L}$. To minimize the adsorption and precipitation on the walls of bottles, the samples were acidified to a $\mathrm{pH}<2.0$ with $\mathrm{HNO}_{3}{ }^{33}$. $\mathrm{Cr}, \mathrm{Mn}, \mathrm{Cu}, \mathrm{As}, \mathrm{Cd}, \mathrm{Ba}, \mathrm{Hg}$, and $\mathrm{Pb}$ in soil and water samples were determined by ICP-OES (Thermo Fisher Scientific, iCAP 7400), operating conditions are shown in Table 1 and all measurements were made in triplicate while Thermo iteva software was used to control the system.

Analytical figures of merit. Accuracy of acid digestion method for soil analysis was assessed by analysis of CRM and recovery (\%) was calculated while the precision was evaluated by the repetition of acid digestion procedure in replicates of ten $(n=10)$ under the same conditions and results of repeatability are expressed in $\%$ 
RSD. Detection limits including LOD and LOQ were estimated as LOD $=3 \sigma / S, L O Q=10 \sigma / S$ respectively where $\sigma$ is $\mathrm{SD}$ (standard deviation) of analytical blank measurement $(n=18)$ while $S$ is the slope of the calibration curve $(\mathrm{y}=\mathrm{mx}+\mathrm{b})^{34,35}$.

Toxic and heavy metals contamination assessment in soil. Geo-accumulation index $\left(\mathrm{I}_{\text {geo }}\right)$, contamination factor (CF) and potential ecological risk index (PERI) can be used to assess pollution, evaluate the pattern of contamination and determine the potential risk due to exposure to ecological sensitivity, concentration and toxicity of TMs and HMs in soil. $\mathrm{I}_{\text {geo }}$ was calculated by using formula ${ }^{11}$.

$$
\mathrm{I}_{\text {geo }}=\log _{2}\left(\frac{\mathrm{C}_{\mathrm{n}}}{1.5 \mathrm{~B}_{\mathrm{n}}}\right)
$$

where $C_{n}$ is the concentration of an element in the soil sample while $B_{n}$ is the geochemical background value of non-effected soil at the site of city. The constant 1.5 allowed us to minimize effect variation in background concentration due to lithogenic impacts ${ }^{36}$. Soil quality can be distinguished by $\mathrm{I}_{\text {geo }}$ index classification as follows, $\mathrm{I}_{\text {geo }} \leq 0$ (uncontaminated), $0<\mathrm{I}_{\text {geo }}<1$ (uncontaminated to moderately contaminated), $1<\mathrm{I}_{\text {geo }}<2$ (moderately contaminated), $2<\mathrm{I}_{\text {geo }}<3$ (moderately to heavily contaminated), $3<\mathrm{I}_{\text {geo }}<4$ (heavily contaminated), $4<\mathrm{I}_{\text {geo }}<5$ (heavily to extremely contaminated), $5<\mathrm{I}_{\text {geo }}$ (extremely contaminated). $\mathrm{CF}$ was estimated by following equation ${ }^{11}$

$$
\mathrm{CF}=\frac{\mathrm{C}_{\mathrm{n}}}{\mathrm{C}_{\mathrm{b}}}
$$

where $C_{n}$ is the concentration of an element in the soil sample while $C_{b}$ is the geochemical background value of non-effected soil at the site of city. Soil quality can be classified by CF value as follows, $\mathrm{CF}<1$ (low contamination), $1 \leq \mathrm{CF}<3$ (moderate contamination), $3 \leq \mathrm{CF}<6$ (considerable contamination), and $\mathrm{CF} \geq 6$ (very high contamination $)^{11}$.

The potential ecological risk of individual metal element can be determined as follows ${ }^{37}$

$$
\mathrm{E}_{\mathrm{r}}^{\mathrm{i}}=\mathrm{C}_{\mathrm{r}}^{\mathrm{i}} \times \mathrm{T}_{\mathrm{r}}^{\mathrm{i}}=\left(\frac{\mathrm{C}_{\mathrm{S}}^{\mathrm{i}}}{\mathrm{C}_{\mathrm{n}}^{\mathrm{i}}}\right) \times \mathrm{T}_{\mathrm{r}}^{\mathrm{i}}
$$

where

$$
\begin{aligned}
& \mathrm{C}_{\mathrm{S}}^{\mathrm{i}}=\text { concentration of an element in the soil sample } \\
& \mathrm{C}_{\mathrm{n}}^{1}=\text { geochemical background value of non-effected soil } \\
& \mathrm{T}_{\mathrm{r}}^{1}=\text { toxic response factor for each metal }
\end{aligned}
$$

Toxic response factor was taken 2 for $\mathrm{Cr}, 5$ for $\mathrm{Cu}$ and $\mathrm{Pb}, 10$ for As, 40 for $\mathrm{Hg}$ and 50 for $\mathrm{Cd}^{38}$. Soil quality can be classified by $\mathrm{E}_{\mathrm{r}}$ value as follows, $\mathrm{E}_{\mathrm{r}}<40$ (low risk), $40 \leq \mathrm{E}_{\mathrm{r}}<80$ (moderate risk), $80 \leq \mathrm{E}_{\mathrm{r}}<160$ (considerable risk), $160 \leq \mathrm{E}_{\mathrm{r}}<320$ (high risk), and $\mathrm{E}_{\mathrm{r}} \geq 320$ (very high risk).

Human health risk assessment. To evaluate the human exposure to TMs and HMs in soil and water, an estimation of risk was determined by using average daily dose (ADD), the non-carcinogenic target hazard quotient (THQ), hazard index (HI), and lifetime carcinogenic risk (LCR) coefficients ${ }^{9,11,39}$.

Average daily dose. $\mathrm{ADD}$ of three exposure pathways of soil including ingestion $\left(\mathrm{ADD}_{\text {ing }}\right)$, inhalation $\left(\mathrm{ADD}_{\text {inh }}\right)$, and dermal contact $\left(\mathrm{ADD}_{\text {derm }}\right)$ in $\mathrm{mg} / \mathrm{kg} /$ day of metals including $\mathrm{Cr}, \mathrm{Mn}, \mathrm{Cu}, \mathrm{As}, \mathrm{Cd}, \mathrm{Ba}, \mathrm{Hg}$, and $\mathrm{Pb}$ was calculated by using the formula $a^{11,37,40,41}$.

$$
\begin{gathered}
\mathrm{ADD}_{i n g}=\mathrm{C} \times \frac{\mathrm{IngR} \times \mathrm{EF} \times \mathrm{ED}}{\mathrm{BW} \times \mathrm{AT}} \times 10^{-6} \\
\mathrm{ADD}_{i n h}=\mathrm{C} \times \frac{\mathrm{InhR} \times \mathrm{EF} \times \mathrm{ED}}{\mathrm{PEF} \times \mathrm{BW} \times \mathrm{AT}} \\
\mathrm{ADD}_{\text {derm }}=\mathrm{C} \times \frac{\mathrm{SA} \times \mathrm{AF} \times \mathrm{ABF} \times \mathrm{EF} \times \mathrm{ED}}{\mathrm{BW} \times \mathrm{AT}} \times 10^{-6}
\end{gathered}
$$

where $\mathrm{C}$ is the concentration of TMs and HMs in $\mathrm{mg} / \mathrm{kg}$, IngR is ingestion rate in $\mathrm{mg} /$ day (IngR $=200$ for children and 100 for adults), EF exposure frequency in days/year (180), ED is exposure duration (6 years for children and 24 years for adults), BW is the average body weight (child $=15 \mathrm{~kg}$ and adult $=70 \mathrm{~kg}$ ), AT is the average time $(365 \times \mathrm{ED})$, InhR is inhalation rate in $\mathrm{mg} / \mathrm{cm}^{2}$ (20 for both adult and children), PEF is particle emission factor in $\mathrm{m}^{3} \mathrm{~kg}^{-1}\left(1.36 \times 10^{9}\right.$ for both adult and children), SA is the surface area of the exposed skin in $\mathrm{cm}^{2}(2145$ for adult and 1150 for children), $\mathrm{AF}$ is the skin adherence factor for the soil in $\mathrm{mg} \mathrm{cm}^{2-1}$ ( 0.2 for adult and 0.07 for children), ABF presents the dermal absorption factor (0.03 for As and 0.001 for other metals). While $\mathrm{ADD}_{\text {ing }}$ and $\mathrm{ADD}_{\text {derm }}$ of water in $\mathrm{mg}^{-1} \mathrm{~kg}^{-1}$ day $^{-1}$ of metals including $\mathrm{Cr}, \mathrm{Mn}, \mathrm{Cu}, \mathrm{As}, \mathrm{Cd}, \mathrm{Ba}, \mathrm{Hg}$, and $\mathrm{Pb}$ was calculated by using the formula given above for soil whereas $\mathrm{IngR}$ is ingestion rate of water is $2.2 \mathrm{~L} \mathrm{day}^{-1}$ for adult and 1.5 $\mathrm{L} \mathrm{day}^{-1}$ for children, EF is 365 days year ${ }^{-1}$, SA is $5700 \mathrm{~cm}^{2}$ and rest of parameters are same as mentioned above. 


\begin{tabular}{|l|l|l|l|l|l|l|}
\hline Metal & $\mathbf{R f D}_{\text {ing }}$ & $\mathbf{R f D}_{\text {inh }}$ & $\mathbf{R f D}_{\text {derm }}$ & $\mathbf{C S F}_{\text {ing }}$ & $\mathbf{C S F}_{\text {inh }}$ & $\mathbf{C S F}_{\text {derm }}$ \\
\hline $\mathrm{Cr}$ & $3 \times 10^{-3}$ & $2.86 \times 10^{-5}$ & $6 \times 10^{-5}$ & 0.5 & - & 41.0 \\
\hline $\mathrm{Mn}$ & $140 \times 10^{-3}$ & $140 \times 10^{-3}$ & $1.8 \times 10^{-3}$ & - & - & - \\
\hline $\mathrm{Cu}$ & $4 \times 10^{-2}$ & $4.02 \times 10^{-2}$ & $1.2 \times 10^{-2}$ & - & - & - \\
\hline $\mathrm{As}$ & $3 \times 10^{-4}$ & $3 \times 10^{-4}$ & $1.23 \times 10^{-4}$ & 1.5 & 1.5 & 1.5 \\
\hline $\mathrm{Cd}$ & $1 \times 10^{-4}$ & $1 \times 10^{-4}$ & $1 \times 10^{-5}$ & 0.38 & - & 6.3 \\
\hline $\mathrm{Ba}$ & $7 \times 10^{-2}$ & $1.43 \times 10^{-4}$ & $4.9 \times 10^{-3}$ & - & - & - \\
\hline $\mathrm{Pb}$ & $3.5 \times 10^{-3}$ & $3.25 \times 10^{-3}$ & $5.25 \times 10^{-4}$ & 0.0085 & - & 0.042 \\
\hline $\mathrm{Hg}$ & $3 \times 10^{-4}$ & $3 \times 10^{-4}$ & $2.1 \times 10^{-5}$ & - & - & - \\
\hline
\end{tabular}

Table 2. RfD and CSF values used in this study ${ }^{39,42}$.

Total hazard quotient and index. THQ is the ratio of ADD (from three exposure pathways) and RfD (chronic reference dose for each metal in $\mathrm{mg} / \mathrm{kg} \mathrm{BW} /$ day) which is typically used to estimate the potential non-carcinogenic risk of metals exposure to humans in three different pathways ${ }^{36}$.

$$
\mathrm{THQ}=\frac{\mathrm{ADD}(\text { ingestion, inhalation or dermal })}{\mathrm{RfD}}
$$

$\mathrm{RfD}$ in $\mathrm{mg} / \mathrm{kg} \mathrm{BW} /$ day for $\mathrm{Cr}, \mathrm{Mn}, \mathrm{Cu}, \mathrm{As}, \mathrm{Cd}, \mathrm{Ba}, \mathrm{Hg}$, and $\mathrm{Pb}$ respectively are presented in Table 2 whereas THQ $<1$ considers the exposed population experience no significant health risk.

Whereas the hazard index (HI) is equal to the sum of all expected HQs (non-carcinogenic risks) through inhalation, oral, and dermal, pathways and is employed to compute the total potential non-carcinogenic risks of different contaminants through the 3 exposure routes mentioned above ${ }^{11}$.

$$
\mathrm{HI}=\Sigma \mathrm{HQ}=\mathrm{HQ}_{\text {ing }}+\mathrm{HQ}_{\text {inh }}+\mathrm{HQ}_{\text {derm }}
$$

If the value of $\mathrm{HI} \leq 1$ then it indicates no significant risk of non-carcinogenic effects. However, when $\mathrm{HI}>1$, there is a probability of non-carcinogenic effects occurring, and the probability increases with a rising value of $\mathrm{HI}^{43,44}$.

Carcinogenic risk assessment. Cancer risk for lifetime exposure (LCR) of $\mathrm{Cr}, \mathrm{As}, \mathrm{Cd}, \mathrm{Pb}$, and $\mathrm{Hg}$ were estimated to determine the health risk by calculating the cumulative life cancer risk rating using the formula below for each exposure pathway ${ }^{45}$ :

$$
\begin{aligned}
\mathrm{LCR} & =\mathrm{ADD}(\text { ingestion, inhalation or dermal }) \times \mathrm{CSF} \\
& =\Sigma \text { cancer risk }=\text { cancer } \text { risk }_{\text {ing }}+{\text { cancer } \text { risk }_{\text {inh }}+\text { cancer risk }_{\text {derm }}}
\end{aligned}
$$

where CSF is the cancer slope factor which is given in Table 2 for each metal for three exposure pathways. Whereas LCR $<10^{-6}$, LCR $>1 \times 10^{-4}$, and LCR $1 \times 10^{-6}$ to $1 \times 10^{-4}$ indicates no carcinogenic risk, high risk of developing cancer, and signifies acceptable risk to humans respectively.

\section{Results and discussion}

Analytical figure of merit. Accuracy is a very important and prime factor in analytical results because these results are subject to errors which cause the results to differ from the true concentration of determinants. The acquired results affecting the ability of decisions based on these results. Various factors such as purity of reagents, standards, the magnitude of matrices effects, instrument's stability, and environmental condition of the laboratory. So to ensure accuracy during the analysis of $\mathrm{Cr}, \mathrm{Mn}, \mathrm{Cu}, \mathrm{As}, \mathrm{Cd}, \mathrm{Ba}, \mathrm{Hg}$, and $\mathrm{Pb}$ in real samples, $\mathrm{CRM}$ (SRM 2709a) of San Joaquin soil and water (SRM 1640a) were analyzed and results were presented in terms of \% recovery studies (Tables $1 S$ and 3). The recovery results were obtained in ranged between 93.2 and $107.6 \%$ that determines the excellent extraction efficiency.

A linear dynamic range of $0.2-1.0 \mu \mathrm{g} \mathrm{mL}^{-1}$ for $\mathrm{Mn}$, and $\mathrm{Cu}, 0.01-500 \mu \mathrm{g} \mathrm{L} \mathrm{L}^{-1}$ for $\mathrm{Cr}$, As, $\mathrm{Cd}$, and $\mathrm{Ba}$, while $0.02-1000 \mu \mathrm{g} \mathrm{L}^{-1}$ for $\mathrm{Pb}$ and $\mathrm{Hg}$ was selected and linear calibration curve in the form of $\mathrm{y}=\mathrm{mx}+\mathrm{b}$ was obtained by plotting the peak height (y) of each concentration in triplicate, against the nominal concentration. Where " $\mathrm{m}$ " represented the slope of the calibration curve and " $\mathrm{b}$ " indicated the intercept. The linear regression equation was demonstrated (Table $2 \mathrm{~S}$ ) and tabulated the necessary parameters. LOD and LOQ determined by proposed methods are as shown in Table 2S. The lower values of detection limits indicate that the method provided adequate sensitivity. The precision study in terms of repeatability $(n=10$, Table $3 S)$ was performed and $\%$ RSD was calculated. The \% RSD values ranged from 0.20 to 6.40 while 0.42 to 4.06 (Table $2 S$ ) were obtained during the analysis of CRM (SRM 2709a) of San Joaquin soil and water (SRM 1640a) respectively.

Application to real samples. The validated acid extraction procedure was applied to soil samples for extraction of $\mathrm{Cr}, \mathrm{Mn}, \mathrm{Cu}, \mathrm{As}, \mathrm{Cd}, \mathrm{Ba}, \mathrm{Hg}$, and $\mathrm{Pb}$, while the water samples were only acidified with to a $\mathrm{pH}<2.0$ with $\mathrm{HNO}_{3}$ subsequently theses were determined by ICP-OES, and results are presented in Table 4 . 


\begin{tabular}{|c|c|c|c|c|c|}
\hline Metal & $\begin{array}{l}\text { Certified value SRM 2709a } \\
\left(\mu \mathrm{g} \mathrm{g}^{-1}\right)\end{array}$ & Measured value $(\bar{x} \pm t s / \sqrt{ } n)$ & $\begin{array}{l}\text { Certified value SRM 1640a ( } \mu \mathrm{g} \\
\mathrm{kg}^{-1} \text { ) }\end{array}$ & Measured value $(\bar{x} \pm t s / \sqrt{ } n)$ & $\begin{array}{l}\text { \% Recovery SRM 2709a/SRM } \\
\text { 1640a }\end{array}$ \\
\hline \multicolumn{6}{|c|}{ Toxic metals } \\
\hline $\mathrm{Cr}$ & $130 \pm 9$ & $132.9 \pm 2.7$ & $40.22 \pm 0.28$ & $39.20 \pm 1.52$ & $102.2 / 97.5$ \\
\hline $\mathrm{Mn}$ & $529 \pm 18$ & $527.9 \pm 1.8$ & $40.07 \pm 0.35$ & $39.13 \pm 1.32$ & $99.8 / 97.6$ \\
\hline $\mathrm{Cu}$ & $33.9 \pm 0.5$ & $33.5 \pm 0.67$ & $85.07 \pm 0.48$ & $85.34 \pm 0.58$ & $98.8 / 100.3$ \\
\hline As & $10.5 \pm 0.3$ & $11.3 \pm 0.52$ & $8.010 \pm 0.067$ & $8.00 \pm 0.59$ & $107.6 / 99.8$ \\
\hline \multicolumn{6}{|c|}{ Heavy metals } \\
\hline $\mathrm{Cd}$ & $0.371 \pm 0.002$ & $0.362 \pm 0.04$ & $3.961 \pm 0.072$ & $3.690 \pm 0.279$ & $97.6 / 93.2$ \\
\hline $\mathrm{Ba}$ & $979 \pm 28$ & $973.3 \pm 7.8$ & $150.60 \pm 0.074$ & $151.88 \pm 1.224$ & $99.4 / 100.8$ \\
\hline $\mathrm{Hg}$ & $0.09 \pm 0.02$ & $0.09 \pm 0.004$ & - & - & $100 /-$ \\
\hline $\mathrm{Pb}$ & $17.3 \pm 0.10$ & $17.8 \pm 0.29$ & $12.005 \pm 0.040$ & $11.887 \pm 0.389$ & $102.9 / 99.0$ \\
\hline
\end{tabular}

Table 3. Measured and certified values of the metals in SRM 2709a and SRM 1640a. $(\bar{x} \pm t s / \sqrt{ } n)=$ mean \pm CI $(p<0.05, \mathrm{n}=6), \mathrm{CI}=$ Confidence interval.

\begin{tabular}{|c|c|c|c|c|c|c|c|c|c|}
\hline Region & $\begin{array}{l}\text { Concentration } \\
(\mathrm{mg} / \mathrm{kg})\end{array}$ & Cr (soil/water) & Mn (soil/water) & $\mathrm{Cu}$ (soil/water) & As (soil/water) & Cd (soil/water) & Ba (soil/water) & Hg (soil/water) & $\mathrm{Pb}$ (soil/water) \\
\hline \multirow{3}{*}{ I } & Min & $114.0 / .001$ & $270.0 / 0.020$ & $40.0 / 0.020$ & $1.0 / 0.008$ & $0.6 / 0.001$ & $105.0 / 0.140$ & $0.020 / 0.007$ & $17.0 / 0.020$ \\
\hline & Max & $165.0 / .002$ & $320.0 / 0.025$ & $80.0 / 0.030$ & $2.1 / 0.011$ & \begin{tabular}{|l|}
$1.0 / 0.001$ \\
\end{tabular} & $125.0 / 0.160$ & $0.025 / 0.010$ & $35.0 / 0.040$ \\
\hline & Mean & $135.8 / .001$ & $291.6 / 0.021$ & $61.2 / 0.026$ & $1.6 / 0.010$ & $0.8 / 0.001$ & $117.0 / 0.148$ & $0.022 / 0.008$ & $23.2 / 0.033$ \\
\hline \multirow{3}{*}{ II } & Min & $70.0 / 0.001$ & $260.0 / 0.008$ & $90.0 / 0.025$ & $1.5 / 0.010$ & $0.7 / 0.001$ & $90.0 / 0.120$ & $0.025 / 0.005$ & $20.0 / 0.030$ \\
\hline & Max & $125.0 / 0.001$ & $345.0 / 0.020$ & $125.0 / 0.030$ & $1.6 / 0.013$ & $1.0 / 0.002$ & $110.0 / 0.170$ & $0.045 / 0.007$ & $55.0 / 0.030$ \\
\hline & Mean & $95.2 / 0.001$ & $300.2 / 0.017$ & $111.0 / 0.026$ & $1.5 / 0.011$ & $0.8 / 0.002$ & $100.2 / 0.139$ & $0.038 / 0.006$ & $33.4 / 0.030$ \\
\hline \multirow{3}{*}{ III } & Min & $65.0 / 0.001$ & \begin{tabular}{|l|}
$365.0 / 0.001$ \\
\end{tabular} & $70.0 / 0.030$ & $1.6 / 0.009$ & $0.1 / 0.001$ & 95.0/0.158 & $0.025 / 0.004$ & $40.0 / 0.030$ \\
\hline & Max & $110.0 / 0.002$ & $350.0 / 0.010$ & $85.0 / 0.035$ & $2.0 / 0.011$ & $0.6 / 0.002$ & $150.0 / 0.160$ & $0.035 / 0.008$ & $55.0 / 0.045$ \\
\hline & Mean & 93.5/0.001 & $302.6 / 0.006$ & $80.0 / 0.032$ & $1.9 / 0.010$ & \begin{tabular}{|l|}
$0.4 / 0.002$ \\
\end{tabular} & $113.9 / 0.160$ & $0.029 / 0.006$ & $49.6 / 0.037$ \\
\hline \multirow{3}{*}{ IV } & Min & $145.0 / 0.001$ & $290.0 / 0.030$ & $30.0 / 0.040$ & $0.5 / 0.009$ & \begin{tabular}{|l|}
$0.6 / 0.001$ \\
\end{tabular} & 93.0/0.160 & $0.005 / 0.008$ & $18.0 / 0.030$ \\
\hline & Max & 535.0/0.002 & $410.0 / 0.040$ & $60.0 / 0.060$ & $0.9 / 0.013$ & $0.9 / 0.002$ & $110.0 / 0.200$ & $0.011 / 0.010$ & $20.0 / 0.045$ \\
\hline & Mean & \begin{tabular}{|l|}
$307.0 / 0.001$ \\
\end{tabular} & \begin{tabular}{|l|}
$343.0 / 0.034$ \\
\end{tabular} & $43.0 / 0.047$ & $0.8 / 0.011$ & $0.8 / 0.001$ & 101.4/0.179 & $0.008 / 0.009$ & $19.0 / 0.038$ \\
\hline \multirow{3}{*}{ Total } & Min & $65.0 / 0.001$ & $260.0 / 0.001$ & $30.0 / 0.020$ & $0.5 / 0.008$ & $0.1 / 0.001$ & $90.0 / 0.120$ & $0.005 / 0.004$ & $17.0 / 0.020$ \\
\hline & Max & \begin{tabular}{|l|}
$535.0 / 0.002$ \\
\end{tabular} & $410.0 / 0.040$ & $125.0 / 0.060$ & $2.1 / 0.013$ & $1.0 / 0.002$ & $150.0 / 0.200$ & $0.045 / 0.010$ & $55.0 / 0.045$ \\
\hline & Mean & $157.87 / 0.001$ & $309.36 / 0.019$ & $73.80 / 0.033$ & $1.44 / 0.010$ & $0.7 / 0.002$ & $108.13 / 0.156$ & $0.024 / 0.006$ & $31.30 / 0.034$ \\
\hline
\end{tabular}

Table 4. Toxic and heavy metals concentration $\left(\mathrm{mg} \mathrm{kg}^{-1}\right)$ in soil and water of Sialkot city $(\mathrm{n}=20)$. Five samples each of soil and water from each region.

The metals were classified into two groups such as TMs and HMs and their concentration in soil was found in the following sequence $\mathrm{Mn}>\mathrm{Cr}>\mathrm{Cu}>\mathrm{As}$ and $\mathrm{Ba}>\mathrm{Pb}>\mathrm{Cd}>\mathrm{Hg}$ respectively whereas their concentration in water was found in the following order $\mathrm{Cu}>\mathrm{Mn}>\mathrm{As}>\mathrm{Cr}$ and $\mathrm{Ba}>\mathrm{Pb}>\mathrm{Hg}>\mathrm{Cd}$ respectively. The concentration of both TMs and HMs (Table $4 \mathrm{~S}$, supplementary data) decreased as sampling point distance increased from the landfill site so it was assumed that the point near the landfill site is most contaminated.

The mean concentration of $\mathrm{Cr}$ in water samples was found under the standard limit while its concentration in the soil samples exceeding the limit set by regulatory agencies like EU (soil: 100-150 $\left.\mathrm{mg} \mathrm{kg}^{-1}\right)^{46}$, US EPA (water: $\left.0.1 \mathrm{mg} \mathrm{L}^{-1}\right)$, and WHO $\left(0.05 \mathrm{mg} \mathrm{L}^{-1}\right)$. Cr being strongly associated with soil and in this study area, its primary source is the migration of landfill leachate into surrounding soil where most of the landfill is waste of industries like tannery and chemical dying. Biological activities of soil are considerably affected by $\mathrm{Cr}$ contamination, chernozem's biota is highly affected by toxic effects of $\mathrm{Cr}$ and reduce its catalysis activity.

$\mathrm{Cu}$ and $\mathrm{Mn}$ concentrations among the TMs were found higher in both soil and water samples around the landfill sites because both the metals are used in the manufacturing of various items including wires, steel equipments, and alloys that find their way into the landfill. Their high concentration could be an indication of the migration of leachate rich in $\mathrm{Cu}$ and $\mathrm{Mn}$ into the surrounding soils. The concentration of $\mathrm{Mn}$ in soil was found within the reference range recommended by WHO (FAO/WHO: 20-10E04 $\mathrm{mg} \mathrm{kg}^{-1}$ ) whereas Cu concentration was found higher than the permissible limit defined by the EU (50-140 $\left.\mathrm{mg} \mathrm{kg}^{-1}\right)^{46}$ and FAO/WHO (36-75 $\left.\mathrm{mg} \mathrm{kg}^{-1}\right)^{47}$. For water samples, the concentration of both the metals was found within the reference range recommended by WHO (Mn: $0.2 \mathrm{mg} \mathrm{L}^{-1}$ and $\left.\mathrm{Cu}: 2.0 \mathrm{mg} \mathrm{L}^{-1}\right)^{48,49}$. Cu is although an essential nutrient but its excess amount in the soil becomes toxic to some beneficial microorganisms and plants, it can inhibit the mineralization of phosphorus and nitrogen, also it has serious human health effects as well as toxic effects on fish and other aquatic organisms ${ }^{50}$. The concentration of $\mathrm{Cu}$ in the soil more than $300 \mathrm{mg} \mathrm{kg}^{-1}$ decreases the yield of rice, affects the germination 


\begin{tabular}{|c|c|c|c|c|c|c|c|c|}
\hline \multirow[b]{2}{*}{ Index } & \multicolumn{4}{|l|}{ TMs } & \multicolumn{4}{|l|}{ HMs } \\
\hline & $\mathrm{Cr}$ & Mn & $\mathrm{Cu}$ & As & Cd & $\mathrm{Ba}$ & $\mathrm{Hg}$ & $\mathbf{P b}$ \\
\hline$I_{\text {geo }}$ & 1.14 & 1.22 & 1.00 & 1.19 & 1.02 & 1.06 & 1.19 & 0.98 \\
\hline CF & 3.31 & 3.49 & 3.02 & 3.43 & 3.04 & 3.14 & 3.43 & 2.97 \\
\hline PERI & 6.618 & - & 15.095 & 34.280 & 152.15 & - & 137.12 & 14.835 \\
\hline
\end{tabular}

Table 5. Geo-accumulation index $\left(\mathrm{I}_{\text {geo }}\right)$, contamination factor $(\mathrm{CF})$ and potential ecological risk index (PERI).

of wheat, and reduces the biomass in shoots and roots of cabbage ${ }^{51}$. The mean concentration of As in both soil and water samples did not exceed the limit recommended by the European Community (soil: $20 \mathrm{mg} \mathrm{kg}^{-1}$ ) and WHO (water: $0.01 \mathrm{mg} \mathrm{kg}^{-1}$ ) 52 . There was a linear relationship observed between the concentration of As in soil and its transfer into the plants, and cultivation in As contaminated soil and irrigation with water severely affect the growth and results in less yield ${ }^{46}$.

The mean concentration of $\mathrm{Cd}$ in both soil and water samples was found under the standard limit set by regulatory agencies like EU (soil: $\left.1-3 \mathrm{mg} \mathrm{kg}^{-1}\right)^{46}$, US EPA (soil: $1.4 \mathrm{mg} \mathrm{kg}^{-1}$, water: $0.005 \mathrm{mg} \mathrm{L}^{-1}$ ) ${ }^{53}$ and WHO $\left(0.005 \mathrm{mg} \mathrm{L}^{-1}\right)$ but this soil is not suitable for gardening and agriculture because Cd concentration exceeds the limit set by US EPA $\left(0.48 \mathrm{mg} \mathrm{kg}^{-1}\right)$ and WHO $\left(0.003 \mathrm{mg} \mathrm{kg}^{-1}\right)$ respectively ${ }^{54}$. Cd being strongly associated with soil and in this study area, its primary source is the migration of landfill leachate into surrounding soil where most of the landfill is waste of industries where it is present as impurities in plant pigments, alloys, galvanized pipes, metal fittings, and solders. The high concentration of $\mathrm{Cd}$ has toxic effects on the beneficial microbes, disturb their metabolic process, and inhibit their growth. Cd has a lengthy biological half (10-35 years) in humans ${ }^{55,56}$. $\mathrm{Ba}$ and $\mathrm{Pb}$ concentrations among the HMs were found higher in both soil and water samples around the landfill sites because both the metals are used in the manufacturing of various items including lead-based paints, lead batteries, rubber products, and glass that find their way into the landfill. The mean concentration of $\mathrm{Ba}$ in soil and water did not exceed the limit set by US EPA (soil: $70-3000 \mathrm{mg} \mathrm{kg}^{-1}$, water: $2.0 \mathrm{mg} \mathrm{L}^{-1}$ ) 57 . Excess of Ba in soil and water may disturb the calcium metabolic process ${ }^{58}$. The mean concentration of $\mathrm{Pb}$ in both soil and water samples were found under the standard limit set by regulatory agencies like EU (soil: $\left.50-300 \mathrm{mg} \mathrm{kg}^{-1}\right)^{46}$, US EPA (soil: $200 \mathrm{mg} \mathrm{kg}^{-1}$, water: $\left.0.05 \mathrm{mg} \mathrm{L}^{-1}\right)^{54}$. Soil microbial mass containing carbon and nitrogen is considerably affected by the higher concentration of $\mathrm{Pb}$ present in it and deteriorate fertility by decreasing the rate of nutrient cycling ${ }^{59}$. In natural sources $\mathrm{Pb}$ is found in limited as compared to anthropogenic sources so its presence in environment is consider as indicator of pollution ${ }^{10}$. The mean concentration of $\mathrm{Hg}$ in both soil and water samples was found under the standard limit set by WHO (soil: $0.08 \mathrm{mg} \mathrm{kg}^{-1}$, water: $0.006 \mathrm{mg} \mathrm{L}^{-1}$ ) but the concentration of $\mathrm{Hg}$ in water exceeding the limit set by the US EPA $\left(0.002 \mathrm{mg} \mathrm{kg}^{-1}\right)^{54}$. Nematodes are one of the most species-rich metazoan phyla in soil ecosystems, live within the interstitial spaces of soils play a vital role in nutrient cycling in soil. These nematodes are affected by the high concentration of Hg. Exposure to human leading to defects in immune response, vital organs, nervous system and reproduction ${ }^{60}$.

Degradation of biodegradable material in landfill also plays an important role for leaching of THs and HMs into water and soil. Large amount of oxygen as oxidant present in the aquifer matrix that induces the reducing conditions and the existing state of these metals is disturbed in groundwater. Since the THs and HMs are covered by high quantities of activated and non-activated colloids, large and small dissolved particles, which resulted in the adsorption of these metals on the pore of the aquifer ${ }^{9}$. This is fact that $\mathrm{Cr}, \mathrm{As}, \mathrm{Cd}$, and $\mathrm{Pb}$ have been found to contribute to large proportions of potential risk with respect to metal contamination in the soil due to human activities. They have been grouped in the priority metals that are important for public health and could damage the multiple organs and were categories as human carcinogens ${ }^{45}$.

Toxic and heavy metals contamination assessment in soil. Geo-accumulation index $\left(\mathrm{I}_{\text {geo }}\right)$, contamination factor (CF) and potential ecological risk index (PERI) were determined to assess pollution, evaluate the pattern of contamination and determine the potential risk due to exposure to ecological sensitivity, concentration and toxicity of TMs and HMs in soil. $\mathrm{I}_{\text {geo }}$ indicated (Table 5) that soil is uncontaminated to moderately contaminated with respect to all metals except the $\mathrm{Cu}$ and $\mathrm{Pb}$ which was categorized as uncontaminated. As with the distribution of $\mathrm{I}_{\text {geo }}$ the soil was considerable contaminated with respect to all metals except $\mathrm{Cu}(\approx 3.0)$, Cd $(\approx 3.0), \mathrm{Pb}(2.97)$ and was categorized as moderately contaminated. Data has shown (Table 5) that considerable ecological risk was measured with respect to soil contaminated with $\mathrm{Cd}$ and $\mathrm{Hg}$ while the low ecological risk was measured due to contribution from $\mathrm{Cr}, \mathrm{Cu}, \mathrm{As}$ and $\mathrm{Pb}$. Furthermore, $\mathrm{Cd}$ and $\mathrm{Hg}$ were long known of their considerable environmental risk. In China, study on HMs composition in water for ecological risk assessment has shown that the contamination with these metals resulted in moderate to high risk. In the current study area, humans can become exposed to TMs and HMs when utilizing the contaminated soils for agricultural activities and accumulation of these in soils leads to increased phyto-accumulation in the crops grown.

Human health risk assessment. Average daily dose. ADD in $\mathrm{mg}^{-1} \mathrm{~kg}^{-1} \mathrm{day}^{-1}$ of metals including $\mathrm{Cr}$, $\mathrm{Mn}, \mathrm{Cu}, \mathrm{As}(\mathrm{TMs})$ and $\mathrm{Cd}, \mathrm{Ba}, \mathrm{Hg}, \mathrm{Pb}(\mathrm{HMs})$ was calculated based on three exposure pathways of soil such as $\mathrm{ADD}_{\text {ing }}, \mathrm{ADD}_{\text {inh }}$, and $\mathrm{ADD}_{\text {derm }}$ while for water $\mathrm{ADD}_{\text {ing }}$ and $\mathrm{ADD}_{\text {derm }}$ were considered. $\mathrm{ADD}$ trend (Table 6) in both adults and children was found in order $\mathrm{ADD}_{\text {ing }}>\mathrm{ADD}_{\text {derm }}>\mathrm{ADD}_{i n h}$ for soil while the same trend was observed for water in both groups (adults and children) such as $\mathrm{ADD}_{\text {ing }}>\mathrm{ADD}_{\text {derm }}$. Among the $\mathrm{ADD}$ of soil, $\mathrm{ADD}_{\text {ing }}$ and $\mathrm{ADD}_{\text {inh }}$ for children had the maximum dose for all metals than adults while $\mathrm{ADD}_{\text {derm }}$ was higher 


\begin{tabular}{|c|c|c|c|c|c|c|}
\hline Metal & $\mathrm{ADD}_{\text {ing }}$ & $\mathrm{ADD}_{i n h}$ & $\mathrm{ADD}_{\text {derm }}$ & $\mathrm{HQ}_{\text {ing }}$ & $\mathrm{HQ}_{\text {inh }}$ & $\mathrm{HQ}_{\text {derm }}$ \\
\hline \multicolumn{7}{|l|}{ Soil } \\
\hline \multicolumn{7}{|l|}{ Adults } \\
\hline $\mathrm{Cr}$ & $1.112 \times 10^{-4}$ & $1.635 \times 10^{-8}$ & $4.767 \times 10^{-7}$ & $3.706 \times 10^{-2}$ & $5.716 \times 10^{-4}$ & $7.945 \times 10^{-3}$ \\
\hline $\mathrm{Mn}$ & $2.179 \times 10^{-4}$ & $3.204 \times 10^{-8}$ & $9.342 \times 10^{-7}$ & $1.556 \times 10^{-3}$ & $2.288 \times 10^{-7}$ & $5.190 \times 10^{-4}$ \\
\hline $\mathrm{Cu}$ & $5.199 \times 10^{-5}$ & $7.645 \times 10^{-9}$ & $2.228 \times 10^{-7}$ & $1.299 \times 10^{-3}$ & $1.901 \times 10^{-7}$ & $1.856 \times 10^{-5}$ \\
\hline As & $1.014 \times 10^{-6}$ & $1.492 \times 10^{-10}$ & $1.305 \times 10^{-7}$ & $3.380 \times 10^{-3}$ & $4.973 \times 10^{-7}$ & $1.060 \times 10^{-3}$ \\
\hline $\mathrm{Cd}$ & $4.931 \times 10^{-7}$ & $7.252 \times 10^{-11}$ & $2.114 \times 10^{-9}$ & $4.931 \times 10^{-3}$ & $7.252 \times 10^{-7}$ & $2.114 \times 10^{-4}$ \\
\hline $\mathrm{Ba}$ & $7.617 \times 10^{-5}$ & $1.120 \times 10^{-8}$ & $3.265 \times 10^{-7}$ & $1.088 \times 10^{-3}$ & $7.832 \times 10^{-5}$ & $6.663 \times 10^{-5}$ \\
\hline $\mathrm{Hg}$ & $1.691 \times 10^{-8}$ & $2.486 \times 10^{-12}$ & $7.248 \times 10^{-11}$ & $5.636 \times 10^{-5}$ & $8.286 \times 10^{-9}$ & $3.451 \times 10^{-6}$ \\
\hline $\mathrm{Pb}$ & $2.205 \times 10^{-5}$ & $3.242 \times 10^{-9}$ & $9.452 \times 10^{-8}$ & $6.300 \times 10^{-3}$ & $9.975 \times 10^{-7}$ & $1.800 \times 10^{-4}$ \\
\hline \multicolumn{7}{|c|}{ Children } \\
\hline $\mathrm{Cr}$ & $1.038 \times 10^{-3}$ & $7.632 \times 10^{-8}$ & $4.177 \times 10^{-7}$ & $3.460 \times 10^{-1}$ & $2.668 \times 10^{-3}$ & $6.961 \times 10^{-3}$ \\
\hline $\mathrm{Mn}$ & $2.034 \times 10^{-3}$ & $1.495 \times 10^{-7}$ & $8.185 \times 10^{-7}$ & $1.452 \times 10^{-2}$ & $1.067 \times 10^{-6}$ & $4.547 \times 10^{-4}$ \\
\hline $\mathrm{Cu}$ & $4.852 \times 10^{-4}$ & $3.568 \times 10^{-8}$ & $1.952 \times 10^{-7}$ & $1.213 \times 10^{-2}$ & $8.875 \times 10^{-7}$ & $1.626 \times 10^{-5}$ \\
\hline As & $9.468 \times 10^{-6}$ & $6.962 \times 10^{-10}$ & $1.143 \times 10^{-7}$ & $3.156 \times 10^{-2}$ & $2.320 \times 10^{-6}$ & $9.292 \times 10^{-4}$ \\
\hline $\mathrm{Cd}$ & $4.603 \times 10^{-6}$ & $3.384 \times 10^{-10}$ & $1.852 \times 10^{-9}$ & $4.603 \times 10^{-2}$ & $3.384 \times 10^{-6}$ & $1.852 \times 10^{-4}$ \\
\hline $\mathrm{Ba}$ & $7.109 \times 10^{-4}$ & $5.227 \times 10^{-8}$ & $2.861 \times 10^{-7}$ & $1.015 \times 10^{-2}$ & $3.655 \times 10^{-4}$ & $5.838 \times 10^{-5}$ \\
\hline $\mathrm{Hg}$ & $1.758 \times 10^{-7}$ & $1.160 \times 10^{-11}$ & $6.350 \times 10^{-11}$ & $5.860 \times 10^{-4}$ & $3.866 \times 10^{-8}$ & $3.023 \times 10^{-6}$ \\
\hline $\mathrm{Pb}$ & $2.058 \times 10^{-4}$ & $1.513 \times 10^{-8}$ & $8.281 \times 10^{-8}$ & $5.880 \times 10^{-2}$ & $4.655 \times 10^{-6}$ & $1.577 \times 10^{-4}$ \\
\hline \multicolumn{7}{|l|}{ Water } \\
\hline \multicolumn{7}{|l|}{ Adults } \\
\hline $\mathrm{Cr}$ & $3.142 \times 10^{-11}$ & - & $1.628 \times 10^{-11}$ & $1.047 \times 10^{-8}$ & - & $2.713 \times 10^{-7}$ \\
\hline $\mathrm{Mn}$ & $5.971 \times 10^{-10}$ & & $3.094 \times 10^{-9}$ & $4.265 \times 10^{-9}$ & - & $1.718 \times 10^{-6}$ \\
\hline $\mathrm{Cu}$ & $1.037 \times 10^{-9}$ & - & $5.374 \times 10^{-10}$ & $2.592 \times 10^{-8}$ & - & $4.478 \times 10^{-8}$ \\
\hline As & $3.142 \times 10^{-10}$ & - & $4.885 \times 10^{-9}$ & $1.047 \times 10^{-6}$ & - & $3.971 \times 10^{-5}$ \\
\hline $\mathrm{Cd}$ & $6.285 \times 10^{-11}$ & - & $3.257 \times 10^{-11}$ & $6.285 \times 10^{-7}$ & - & $3.257 \times 10^{-6}$ \\
\hline $\mathrm{Ba}$ & $4.902 \times 10^{-9}$ & - & $2.540 \times 10^{-9}$ & $7.002 \times 10^{-8}$ & - & $5.183 \times 10^{-7}$ \\
\hline $\mathrm{Hg}$ & $2.200 \times 10^{-10}$ & - & $1.140 \times 10^{-10}$ & $7.333 \times 10^{-7}$ & - & $5.428 \times 10^{-6}$ \\
\hline $\mathrm{Pb}$ & $1.068 \times 10^{-9}$ & - & $5.537 \times 10^{-10}$ & $3.051 \times 10^{-7}$ & - & $1.054 \times 10^{-6}$ \\
\hline \multicolumn{7}{|c|}{ Children } \\
\hline $\mathrm{Cr}$ & $1.000 \times 10^{-10}$ & - & $2.660 \times 10^{-11}$ & $3.333 \times 10^{-8}$ & - & $4.433 \times 10^{-7}$ \\
\hline $\mathrm{Mn}$ & $1.900 \times 10^{-9}$ & - & $5.054 \times 10^{-10}$ & $1.357 \times 10^{-8}$ & - & $2.807 \times 10^{-7}$ \\
\hline $\mathrm{Cu}$ & $3.300 \times 10^{-9}$ & - & $8.778 \times 10^{-10}$ & $8.250 \times 10^{-8}$ & - & $7.315 \times 10^{-8}$ \\
\hline As & $1.000 \times 10^{-9}$ & - & $7.980 \times 10^{-9}$ & $3.333 \times 10^{-6}$ & - & $6.487 \times 10^{-5}$ \\
\hline $\mathrm{Cd}$ & $2.000 \times 10^{-10}$ & - & $5.320 \times 10^{-11}$ & $2.000 \times 10^{-6}$ & - & $5.320 \times 10^{-6}$ \\
\hline $\mathrm{Ba}$ & $1.560 \times 10^{-8}$ & - & $4.149 \times 10^{-9}$ & $2.228 \times 10^{-7}$ & - & $4.546 \times 10^{-7}$ \\
\hline $\mathrm{Hg}$ & $7.000 \times 10^{-10}$ & - & $1.862 \times 10^{-10}$ & $2.333 \times 10^{-6}$ & - & $8.866 \times 10^{-6}$ \\
\hline $\mathrm{Pb}$ & $3.400 \times 10^{-9}$ & - & $9.044 \times 10^{-10}$ & $9.714 \times 10^{-7}$ & - & $1.722 \times 10^{-6}$ \\
\hline
\end{tabular}

Table 6. Results of ADD and HQ values from soil and water for adults and children.

in adults. In the case of water, the data showed more exposure of metals to children than adults. In conclusion, children are exposed to TMs and HMs more than adults.

Total hazard quotient and index. HQ trend (Table 6) in both adults and children was found in order $\mathrm{HQ}_{\text {ing }}>\mathrm{HQ}_{\text {derm }}>\mathrm{HQ}_{\text {inh }}$ for soil for all metals except $\mathrm{Ba}$ which followed $\mathrm{HQ}_{\text {ing }}>\mathrm{HQ}_{\text {inh }}>\mathrm{HQ}_{\text {derm }}$. Whereas $\mathrm{HQ}$ trend in both adults and children was found in order $\mathrm{HQ}_{\text {derm }}>\mathrm{HQ}_{\text {ing }}$ for water except the $\mathrm{Cu}$ in children was found in order of $\mathrm{HQ}_{\text {ing }}>\mathrm{HQ}_{\text {derm }}$. $\mathrm{HI}$ values for an individual metal by all exposure pathways of soil and water in both adults and children was less than one which indicates no significant health risk. $\mathrm{HI}$, values of $\mathrm{Cr}$ and $\mathrm{Pb}$ in children were 7 and 7.5 times higher than adults respectively. So, data from Table 7, demonstrated that the HI value for all metals in both soil and water is $<1$ which indicated no significant health risk.

Carcinogenic risk assessment. The carcinogenic slope factor was used to assess the carcinogenic risk from a lifetime exposure of TMs ( $\mathrm{Cr}, \mathrm{Mn}, \mathrm{Cu}, \mathrm{As})$ and $\mathrm{HMs}(\mathrm{Cd}, \mathrm{Ba}, \mathrm{Hg}, \mathrm{Pb})$ by different exposure pathways like ingestion, inhalation, and dermal. LCR $<10^{-6}$, LCR $>1 \times 10^{-4}$, and LCR $1 \times 10^{-6}$ to $1 \times 10^{-4}$ indicates no carcinogenic risk, high risk of developing cancer, and signifies acceptable risk to humans respectively. LCR value for Cr by different exposure pathways of soil was $5.361 \times 10^{-4}$ for children which are at the lower borderline of risk for can- 


\begin{tabular}{|c|c|c|c|c|}
\hline Metal & HI & Interpretation & LCR & Interpretation \\
\hline \multicolumn{5}{|l|}{ Soil } \\
\hline \multicolumn{5}{|l|}{ Adults } \\
\hline $\mathrm{Cr}$ & $4.557 \times 10^{-2}$ & No significant risk & $7.514 \times 10^{-5}$ & No carcinogenic risk \\
\hline $\mathrm{Mn}$ & $2.075 \times 10^{-3}$ & No significant risk & - & - \\
\hline $\mathrm{Cu}$ & $1.317 \times 10^{-3}$ & No significant risk & - & - \\
\hline As & $4.440 \times 10^{-3}$ & No significant risk & $1.717 \times 10^{-6}$ & No carcinogenic risk \\
\hline $\mathrm{Cd}$ & $5.143 \times 10^{-3}$ & No significant risk & $2.006 \times 10^{-7}$ & No carcinogenic risk \\
\hline $\mathrm{Ba}$ & $1.232 \times 10^{-3}$ & No significant risk & - & - \\
\hline $\mathrm{Hg}$ & $5.981 \times 10^{-5}$ & No significant risk & - & - \\
\hline $\mathrm{Pb}$ & $6.480 \times 10^{-3}$ & No significant risk & $1.914 \times 10^{-7}$ & No carcinogenic risk \\
\hline \multicolumn{5}{|c|}{ Children } \\
\hline $\mathrm{Cr}$ & $3.556 \times 10^{-1}$ & No significant risk & $5.361 \times 10^{-4}$ & Carcinogenic risk \\
\hline $\mathrm{Mn}$ & $1.497 \times 10^{-2}$ & No significant risk & - & - \\
\hline $\mathrm{Cu}$ & $1.214 \times 10^{-2}$ & No significant risk & - & - \\
\hline As & $3.249 \times 10^{-2}$ & No significant risk & $1.437 \times 10^{-5}$ & No carcinogenic risk \\
\hline $\mathrm{Cd}$ & $4.621 \times 10^{-2}$ & No significant risk & $1.760 \times 10^{-6}$ & No carcinogenic risk \\
\hline $\mathrm{Ba}$ & $1.057 \times 10^{-2}$ & No significant risk & - & - \\
\hline $\mathrm{Hg}$ & $9.756 \times 10^{-4}$ & No significant risk & - & - \\
\hline $\mathrm{Pb}$ & $5.896 \times 10^{-2}$ & No significant risk & $1.752 \times 10^{-6}$ & No carcinogenic risk \\
\hline \multicolumn{5}{|l|}{ Water } \\
\hline \multicolumn{5}{|l|}{ Adults } \\
\hline $\mathrm{Cr}$ & $2.817 \times 10^{-7}$ & No significant risk & $6.831 \times 10^{-10}$ & No carcinogenic risk \\
\hline $\mathrm{Mn}$ & $1.722 \times 10^{-6}$ & No significant risk & - & - \\
\hline $\mathrm{Cu}$ & $7.070 \times 10^{-8}$ & No significant risk & - & - \\
\hline As & $4.075 \times 10^{-5}$ & No significant risk & $7.798 \times 10^{-9}$ & No carcinogenic risk \\
\hline $\mathrm{Cd}$ & $3.885 \times 10^{-6}$ & No significant risk & $2.289 \times 10^{-10}$ & No carcinogenic risk \\
\hline $\mathrm{Ba}$ & $5.883 \times 10^{-7}$ & No significant risk & - & - \\
\hline $\mathrm{Hg}$ & $6.161 \times 10^{-6}$ & No significant risk & - & - \\
\hline $\mathrm{Pb}$ & $1.359 \times 10^{-6}$ & No significant risk & $3.233 \times 10^{-11}$ & No carcinogenic risk \\
\hline \multicolumn{5}{|c|}{ Children } \\
\hline $\mathrm{Cr}$ & $4.776 \times 10^{-7}$ & No significant risk & $1.140 \times 10^{-9}$ & No carcinogenic risk \\
\hline $\mathrm{Mn}$ & $2.942 \times 10^{-7}$ & No significant risk & - & - \\
\hline $\mathrm{Cu}$ & $1.556 \times 10^{-7}$ & No significant risk & - & - \\
\hline As & $6.820 \times 10^{-5}$ & No significant risk & $1.347 \times 10^{-8}$ & No carcinogenic risk \\
\hline $\mathrm{Cd}$ & $7.320 \times 10^{-6}$ & No significant risk & $4.111 \times 10^{-10}$ & No carcinogenic risk \\
\hline $\mathrm{Ba}$ & $6.774 \times 10^{-7}$ & No significant risk & - & - \\
\hline $\mathrm{Hg}$ & $1.119 \times 10^{-5}$ & No significant risk & - & - \\
\hline $\mathrm{Pb}$ & $2.693 \times 10^{-6}$ & No significant risk & $6.688 \times 10^{-11}$ & No carcinogenic risk \\
\hline
\end{tabular}

Table 7. Results of HI and LCR values from soil and water for adults and children.

cer (Table 7). Therefore children are more at risk than adults in this study area where ingestion route is a major contributor to access LCR followed by dermal and inhalation pathways.

$I_{\text {geo }}$, CF and PERI evaluated the pattern of contamination and determine the potential risk due to exposure to ecological sensitivity while the ADD, THQ, and CR coefficients were demonstrated to evaluate the human health risk, is the strength of present research. Whereas the remediation approach is to create a final solution that is protective of human health and the environment is limitation of this research work did on soil and water near landfill site.

\section{Conclusion}

In this study, the concentration of toxic $(\mathrm{Cr}, \mathrm{Mn}, \mathrm{Cu}, \mathrm{As})$ and heavy metals $(\mathrm{Cd}, \mathrm{Ba}, \mathrm{Hg}, \mathrm{Pb})$ in soil and water samples near the landfill site of industrial waste in Sialkot, province of Punjab-Pakistan, was determined by ICP-OES. Toxic and heavy metals concentration in soil was found in following sequence $\mathrm{Mn}>\mathrm{Cr}>\mathrm{Cu}>\mathrm{As}$ and $\mathrm{Ba}>\mathrm{Pb}>\mathrm{Cd}>\mathrm{Hg}$ respectively whereas their concentration in water was found in following order $\mathrm{Cu}>\mathrm{Mn}>\mathrm{As}>\mathrm{Cr}$ and $\mathrm{Ba}>\mathrm{Pb}>\mathrm{Hg}>\mathrm{Cd}$ respectively. The mean concentration of all metals in both soil and water samples $(n=20$, each) was found under the standard limit set by regulatory agencies like EU, US EPA, and WHO, except the $\mathrm{Cr}$, this soil is not suitable for gardening because the $\mathrm{Cr}$ and $\mathrm{Cd}$ concentration found exceeds the limit set by US EPA. As with the distribution of $\mathrm{I}_{\text {geo }}$ the soil was considerable contaminated with respect to all metals 
except $\mathrm{Cu}(\approx 3.0), \mathrm{Cd}(\approx 3.0), \mathrm{Pb}(2.97)$ and was categorized as moderately contaminated. The results indicated that among the $\mathrm{ADD}$ of soil, $\mathrm{ADD}_{\text {ing }}$ and $\mathrm{ADD}_{\text {inh }}$ for children had the maximum dose for all metals than adults while $\mathrm{ADD}_{\text {derm }}$ was higher in adults and $\mathrm{HI}$ value for all metals in both soil and water is $<1$ which indicated no significant health risk. In this study area, children are more at risk than adults where the ingestion route is a major contributor to access LCR followed by dermal and inhalation pathways. Based on the results of human health risk assessments, metals present in soil and water pose negligible non-carcinogenic and carcinogenic risks to the adults and children living in the area under study. But need for the attention and actions of the minimization and prevention of toxic and heavy metal contamination in soil and water by retardation of leachate movement via the appropriate design of new dumping sites with proper foundations. The present observations present useful information regarding the contamination of soil and water with toxic and heavy metals in an industrial area, also has much significance in the area where there are inappropriate practices in solid waste management.

Since these toxic and heavy metals can bio-accumulate, efforts should be made by Government agencies in alleviating their level in soil and water, and this research is useful in taking protective measures to save urban environment. Government agencies should consider new technologies with better capacities for removing these metals from landfill to prevent it discharge into soil and water. Construction of vertical engineered barriers (VEB), caps, and liners can be used to prevent the leaching of these metals into soil and water. So the human exposure to soil and water indicates the necessity of future interventions and policy responses.

Received: 8 June 2021; Accepted: 14 July 2021

Published online: 20 August 2021

\section{References}

1. Naveen, B., Mahapatra, D. M., Sitharam, T., Sivapullaiah, P. \& Ramachandra, T. Physico-chemical and biological characterization of urban municipal landfill leachate. Environ. Pollut. 220, 1-12 (2017).

2. Kassim, S. M. Macromolecular Symposia 43-50 (Wiley, 2012).

3. Gonzalez-Valencia, R., Magana-Rodriguez, F., Cristóbal, J. \& Thalasso, F. Hotspot detection and spatial distribution of methane emissions from landfills by a surface probe method. Waste Manag. 55, 299-305 (2016).

4. Adamcová, D. et al. Environmental assessment of the effects of a municipal landfill on the content and distribution of heavy metals in Tanacetum vulgare L. Chemosphere 185, 1011-1018 (2017).

5. Samadder, S., Prabhakar, R., Khan, D., Kishan, D. \& Chauhan, M. Analysis of the contaminants released from municipal solid waste landfill site: A case study. Sci. Total Environ. 580, 593-601 (2017).

6. Edokpayi, J. N., Durowoju, O. S. \& Odiyo, J. O. Assessment of heavy metals in landfill leachate: A case study of Thohoyandou landfill, Limpopo Province South Africa. Heavy Met. 16, 214-227 (2018).

7. Grugnaletti, M., Pantini, S., Verginelli, I. \& Lombardi, F. An easy-to-use tool for the evaluation of leachate production at landfill sites. Waste Manag. 55, 204-219 (2016).

8. Mavakala, B. K. et al. Leachates draining from controlled municipal solid waste landfill: Detailed geochemical characterization and toxicity tests. Waste Manag. 55, 238-248 (2016).

9. Boateng, T. K., Opoku, F. \& Akoto, O. Heavy metal contamination assessment of groundwater quality: A case study of Oti landfill site, Kumasi. Appl. Water Sci. 9, 33 (2019).

10. Wu, Z., Zhang, L., Xia, T., Jia, X. \& Wang, S. Heavy metal pollution and human health risk assessment at mercury smelting sites in Wanshan district of Guizhou Province, China. RSC Adv. 10, 23066-23079 (2020).

11. Mohammadi, A. A. et al. Assessment of heavy metal pollution and human health risks assessment in soils around an industrial zone in Neyshabur, Iran. Biol. Trace Elem. Res. 630, 1-10 (2019).

12. Alexander, P., Alloway, B. \& Dourado, A. Genotypic variations in the accumulation of $\mathrm{Cd}, \mathrm{Cu}, \mathrm{Pb}$ and $\mathrm{Zn}$ exhibited by six commonly grown vegetables. Environ. Pollut. 144, 736-745 (2006).

13. Zhu, F., Fan, W., Wang, X., Qu, L. \& Yao, S. Health risk assessment of eight heavy metals in nine varieties of edible vegetable oils consumed in China. Food Chem. Toxicol. 49, 3081-3085 (2011).

14. Bahadır, Z. et al. Separation and preconcentration of lead, chromium and copper by using with the combination coprecipitationflame atomic absorption spectrometric determination. J. Ind. Eng. Chem. 20, 1030-1034 (2014).

15. Santamaria, A. Manganese exposure, essentiality \& toxicity. Indian J. Med. Res. 128, 484 (2008).

16. Rahman, M. A., Rahman, M. M., Reichman, S. M., Lim, R. P. \& Naidu, R. Heavy metals in Australian grown and imported rice and vegetables on sale in Australia: Health hazard. Ecotoxicol. Environ. Saf. 100, 53-60 (2014).

17. Gaetke, L. M. \& Chow, C. K. Copper toxicity, oxidative stress, and antioxidant nutrients. Toxicology 189, 147-163 (2003).

18. Harmanescu, M., Alda, L. M., Bordean, D. M., Gogoasa, I. \& Gergen, I. Heavy metals health risk assessment for population via consumption of vegetables grown in old mining area; a case study: Banat County, Romania. Chem. Cent. J. 5, 64 (2011).

19. Hartley, W. \& Lepp, N. W. Remediation of arsenic contaminated soils by iron-oxide application, evaluated in terms of plant productivity, arsenic and phytotoxic metal uptake. Sci. Total Environ. 390, 35-44 (2008).

20. Jia, Z., Li, S. \& Wang, L. Assessment of soil heavy metals for eco-environment and human health in a rapidly urbanization area of the upper Yangtze Basin. Sci. Rep. 8, 1-14 (2018).

21. Klaassen, C. D., Liu, J. \& Diwan, B. A. Metallothionein protection of cadmium toxicity. Toxicol. Appl. Pharmacol. 238, 215-220 (2009).

22. Lin, Y.-S. et al. Increased risk of cancer mortality associated with cadmium exposures in older Americans with low zinc intake. J. Toxicol. Environ. Health, Part A 76, 1-15 (2013).

23. Oskarsson, A. Handbook on the Toxicology of Metals 625-634 (Elsevier, 2015).

24. Valko, M., Rhodes, C., Moncol, J., Izakovic, M. \& Mazur, M. Free radicals, metals and antioxidants in oxidative stress-induced cancer. Chem.-Biol. Interact. 160, 1-40 (2006).

25. Tchounwou, P. B., Yedjou, C. G., Patlolla, A. K. \& Sutton, D. J. Molecular, Clinical and Environmental Toxicology 133-164 (Springer, 2012).

26. Ekong, E. B., Jaar, B. \& Weaver, V. Lead-related nephrotoxicity: A review of the epidemiologic evidence. Kidney Int. 70, 2074-2084 (2006).

27. Navas-Acien, A., Guallar, E., Silbergeld, E. K. \& Rothenberg, S. J. Lead exposure and cardiovascular disease-A systematic review. Environ. Health Perspect. 115, 472 (2007).

28. Nieboer, E., Tsuji, L. J., Martin, I. D. \& Liberda, E. N. Human biomonitoring issues related to lead exposure. Environ. Sci. Process. Impacts 15, 1824-1829 (2013). 
29. Shams, M. et al. Heavy metals exposure, carcinogenic and non-carcinogenic human health risks assessment of groundwater around mines in Joghatai, Iran. Int. J. Environ. Anal. Chem. 7, 1-16 (2020).

30. Sadeghi, H., Fazlzadeh, M., Zarei, A., Mahvi, A. H. \& Nazmara, S. Spatial distribution and contamination of heavy metals in surface water, groundwater and topsoil surrounding Moghan's tannery site in Ardabil, Iran. Int. J. Environ. Anal. Chem. 9, 1-11 (2020).

31. Seifi, M. et al. Spatial distribution, enrichment and geo-accumulation of heavy metals in surface sediments near urban and industrial areas in the Persian Gulf. Desalin. Water Treat. 158, 130-139 (2019).

32. Epa, U. Method 3050B. Acid digestion of sediments, sludges, and soils. Revision 2, 12 (1996).

33. Federation, W. E. \& Association, A. P. H. Standard Methods for the Examination of Water and Wastewater (American Public Health Association (APHA), 2005).

34. Costa, F. S. et al. Multivariate optimization of an ultrasound-assisted extraction procedure for the determination of $\mathrm{Cu}, \mathrm{Fe}, \mathrm{Mn}$, and $\mathrm{Zn}$ in plant samples by flame atomic absorption spectrometry. Anal. Methods 12, 2509-2512 (2020).

35. Ahmed, M. et al. Optimization and validation procedure for elemental composition of fresh and pasteurized milk in Pakistan employing microwave digestion followed by ICP-OES: A contribution to risk assessment. Food Anal. Methods 9, 2933-2942 (2016).

36. Chonokhuu, S. et al. Contamination and health risk assessment of heavy metals in the soil of major cities in mongolia. Int. J. Environ. Res. Public. Health 16, 2552 (2019).

37. Hanfi, M. Y. \& Yarmoshenko, I. V. Health risk assessment quantification from heavy metals contamination in the urban soil and urban surface deposited sediment. J. Taibah Univ. Sci. 14, 285-293 (2020).

38. Zhang, L. \& Liu, J. In situ relationships between spatial-temporal variations in potential ecological risk indexes for metals and the short-term effects on periphyton in a macrophyte-dominated lake: A comparison of structural and functional metrics. Ecotoxicology 23, 553-566 (2014).

39. Kamunda, C., Mathuthu, M. \& Madhuku, M. Health risk assessment of heavy metals in soils from Witwatersrand Gold Mining Basin, South Africa. Int. J. Environ. Res. Public. Health 13, 663 (2016).

40. Dehghani, M. H., Zarei, A., Yousefi, M., Asghari, F. B. \& Haghighat, G. A. Fluoride contamination in groundwater resources in the southern Iran and its related human health risks. Desalin. Water Treat. 153, 95-104 (2019).

41. Karimi, A. et al. Assessment of human health risks and pollution index for heavy metals in farmlands irrigated by effluents of stabilization ponds. Environ. Sci. Pollut. Res. 27, 1-11 (2020).

42. Agency, U. E. P. (Office of Solid Waste and Emergency Response, 1991).

43. Radfard, M. et al. Drinking water quality and arsenic health risk assessment in Sistan and Baluchestan, Southeastern Province, Iran. Hum. Ecol. Risk Assess.: Int. J. (2018).

44. Qasemi, M. et al. Cadmium in groundwater consumed in the rural areas of Gonabad and Bajestan, Iran: Occurrence and health risk assessment. Biol. Trace Elem. Res. 192, 106-115 (2019).

45. Kusin, F. M., Azani, N. N. M., Hasan, S. N. M. S. \& Sulong, N. A. Distribution of heavy metals and metalloid in surface sediments of heavily-mined area for bauxite ore in Pengerang, Malaysia and associated risk assessment. CATENA 165, 454-464 (2018).

46. Waseem, A. et al. Pollution status of Pakistan: A retrospective review on heavy metal contamination of water, soil, and vegetables. BioMed Res. Int. 2014, Article ID 813206, 29 (2014).

47. Onyedikachi, U. B., Belonwu, D. C. \& Wegwu, M. O. Human health risk assessment of heavy metals in soils and commonly consumed food crops from quarry sites located at Isiagwu, Ebonyi State. Ovidius Univ. Ann. Chem. 29, 8-24 (2018).

48. World Health Organization. Manganese in Drinking-Water: Background Document for Development of WHO Guidelines for Drinking-Water Quality (World Health Organization, 2004).

49. Edition, F. Guidelines for drinking-water quality. WHO Chron. 38, 104-108 (2011).

50. Romić, M., Matijević, L., Bakić, H. \& Romić, D. Environmental Risk Assessment of Soil Contamination (IntechOpen, 2014).

51. Chiou, W.-Y. \& Hsu, F.-C. Copper toxicity and prediction models of copper content in leafy vegetables. Sustainability 11, 6215 (2019).

52. Kabir, M. et al. Spatial variation of arsenic in soil, irrigation water, and plant parts: A microlevel study. Sci. World J. 2016, Article ID 2186069, 14 (2016).

53. Mekonnen, B., Haddis, A. \& Zeine, W. Assessment of the effect of solid waste dump site on surrounding soil and river water quality in Tepi TOWN, Southwest Ethiopia. J. Environ. Public Health 2020, Article ID 5157046, 9 (2020).

54. Kinuthia, G. K. et al. Levels of heavy metals in wastewater and soil samples from open drainage channels in Nairobi, Kenya: Community health implication. Sci. Rep. 10, 1-13 (2020).

55. Liao, M., Luo, Y.-K., Zhao, X.-M. \& Huang, C.-Y. Toxicity of cadmium to soil microbial biomass and its activity: Effect of incubation time on Cd ecological dose in a paddy soil. J. Zhejiang Univ. Sci. B 6, 324 (2005).

56. Agoro, M. A., Adeniji, A. O., Adefisoye, M. A. \& Okoh, O. O. Heavy metals in wastewater and sewage sludge from selected municipal treatment plants in Eastern Cape Province, South Africa. Water 12, 2746 (2020).

57. US-EPA. Secondary drinking water standards: Guidance for nuisance chemicals. In Drinking Water Contaminants-Standards and Regulations EPA 822-F-18-001 (US-EPA, 2017).

58. Vodyanitskii, Y. N. Standards for the contents of heavy metals in soils of some states. Ann. Agrar. Sci. 14, 257-263 (2016).

59. Zeng, L.-S., Liao, M., Chen, C.-L. \& Huang, C.-Y. Effects of lead contamination on soil microbial activity and rice physiological indices in soil-Pb-rice (Oryza sativa L.) system. Chemosphere 65, 567-574 (2006).

60. Martinez, J. G., Quiobe, S. P. \& Moens, T. Effects of mercury (Hg) on soil nematodes: A microcosm approach. Arch. Environ. Contam. Toxicol. 77, 421-431 (2019).

\section{Acknowledgements}

This research work was funded by Institutional Fund Projects under grant no (IFPIP: 95-665-1442). Therefore, authors gratefully acknowledged technical and financial support from the Ministry of Education and King Abdulaziz University, Jeddah, Saudi Arabia.

\section{Author contributions}

W.A.: Methodology, Formal analysis, R.D.A.: Review and editing, M.Z.: Supervision, Review and editing, M.A.: Investigation, Methodology, Formal analysis, Writing-original draft. A.H.: Review and editing, S.R.: Review and editing.

\section{Competing interests}

The authors declare no competing interests.

Additional information

Supplementary Information The online version contains supplementary material available at https://doi.org/ 10.1038/s41598-021-94616-4. 
Correspondence and requests for materials should be addressed to R.D.A., M.Z. or M.A.

Reprints and permissions information is available at www.nature.com/reprints.

Publisher's note Springer Nature remains neutral with regard to jurisdictional claims in published maps and institutional affiliations.

(c) (i) Open Access This article is licensed under a Creative Commons Attribution 4.0 International cc) License, which permits use, sharing, adaptation, distribution and reproduction in any medium or format, as long as you give appropriate credit to the original author(s) and the source, provide a link to the Creative Commons licence, and indicate if changes were made. The images or other third party material in this article are included in the article's Creative Commons licence, unless indicated otherwise in a credit line to the material. If material is not included in the article's Creative Commons licence and your intended use is not permitted by statutory regulation or exceeds the permitted use, you will need to obtain permission directly from the copyright holder. To view a copy of this licence, visit http://creativecommons.org/licenses/by/4.0/.

(C) The Author(s) 2021 